\title{
Effect of exclusive breastfeeding and complementary feeding on infant growth and morbidity
}

T. Khadivzadeh ${ }^{1}$ and S. Parsai ${ }^{2}$

$$
\begin{aligned}
& \text { تأثير الاقتصار على الإرضاع من الثدي والتغذية التكميلية على نمو الطفل وإصابته بالأمراض }
\end{aligned}
$$

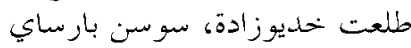

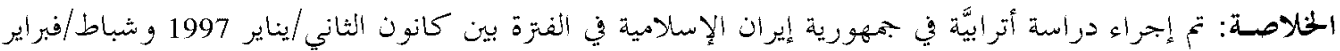

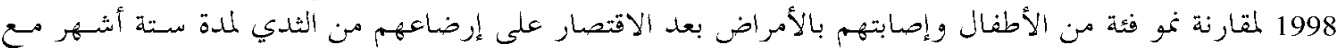

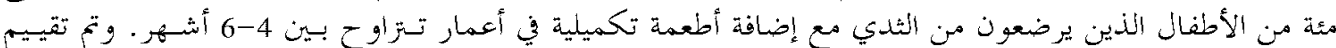

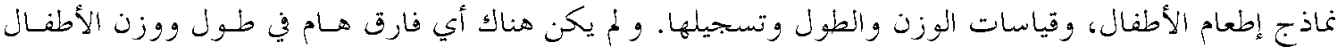

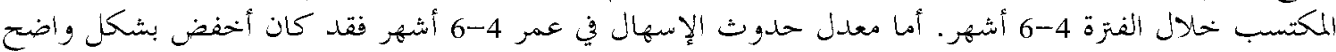

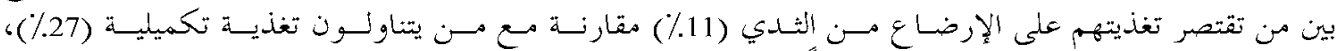

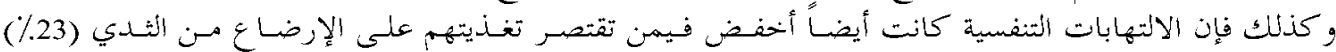

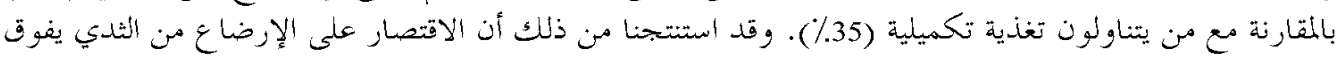

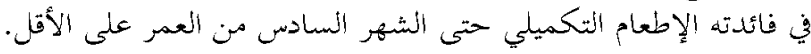

ABSTRACT A cohort study was conducted in the Islamic Republic of Iran between January 1997 and February 1998 to compare the growth and morbidity of 100 infants who were exclusively breastfed for 6 months and 100 who received breast milk and complementary foods between 4-6 months. Infants' feeding pattern, weight and height were assessed and recorded. There were no significant differences in infants' weight and height gain between 4 and 6 months. The rate of diarrhoea between ages 4 and 6 months was significantly lower in exclusively breastfed infants than in complementary food-fed infants (11\% versus $27 \%$ ) and respiratory infections were also lower ( $23 \%$ versus $35 \%$ ). We conclude that exclusive breastfeeding is superior at least until an infant is 6 months of age.

\begin{abstract}
Effet de l'alimentation au sein exclusive et de l'alimentation complémentaire sur la croissance et la morbidité des nourrissons

RESUME Une étude de cohorte a été réalisée en République islamique d'Iran entre janvier 1997 et février 1998 pour comparer la croissance et la morbidité de 100 nourrissons qui ont été exclusivement nourris au sein pendant 6 mois et de 100 nourrissons qui ont reçu du lait maternel et des aliments de complément entre l'âge de 4 et de 6 mois. Le mode d'alimentation, le poids et la taille des nourrissons ont été évalués et consignés. II n'y avait aucune différence significative dans le gain de poids et de taille des nourrissons entre 4 et 6 mois. Le taux de diarrhée entre l'âge de 4 et 6 mois était significativement moins élevé chez les enfants nourris exclusivement au sein que chez les enfants ayant reçu une alimentation complémentaire ( $11 \%$ contre $27 \%$ ) et les infections respiratoires étaient également moins nombreuses (23\% contre $35 \%$ ). Nous concluons que l'allaitement au sein exclusif est supérieur au moins jusqu'à ce que le nourrisson ait atteint l'âge de 6 mois.
\end{abstract}

${ }^{1}$ Educational Development Centre, Meshed University of Medical Sciences, Meshad, Islamic Republic of Iran.

${ }^{2}$ Department of Social Medicine, Shaheed Beheshti University of Medical Sciences, Tehran, Islamic Republic of Iran.

Received 29/11/01; accepted 21/07/02

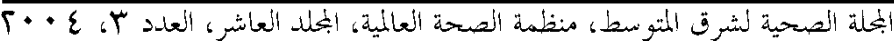




\section{Introduction}

Breastfeeding provides significant nutritional, health and psychological benefits to both mothers and infants [1]. It is suggested by the World Health Organization and the United Nations Children's Fund (WHO/ UNICEF) that exclusive breastfeeding is adequate for the first 4 to 6 months of life [2]. Mothers are advised by the Iranian National Breastfeeding Committee to breastfeed their infants exclusively up to 6 months of life. There has been no research in the Islamic Republic of Iran to investigate the effect of this approach on infant growth and health.

Some investigations have claimed that breastfeeding provides the required nutrition in the first 2 or 3 months of life, but later cannot provide adequate growth for many infants $[3,4]$. In other investigations, exclusive breastfeeding was considered to provide sufficient growth and health up to 6 months of age [5-11] or provide more weight gain [12].

This study was conducted in Meshed from January 1997 to February 1998 in order to compare the growth and morbidity of infants who were exclusively breastfed for 6 months and those who were given complementary foods between 4-6 months old.

\section{Methods}

Meshed is the largest city of Khorasan Razavi province in the north-east of the Islamic Republic of Iran. Based on the 1996 census, Meshed's urban population was 1887405 , of whom 31598 were under 1 year old.

\section{Participants}

The sample of this cohort study comprised 200 healthy, full-term infants who received health care at 5 health care centres randomly selected from 54 urban health care centres in Meshed. The criteria for entry to the study were: all babies at the end of the 4th month of life who had been exclusively breast-fed, had normal growth, were healthy at entry to the study and whose mother was healthy and attended mother and child health care on a regular basis. In order to recruit infants fulfilling these criteria, 498 pairs of mothers were interviewed. Two equal groups were formed: 100 mothers who had decided to continue exclusive breastfeeding until the end of 6 months after the birth, and 100 mothers who had decided to use complementary foods after 4 months, based on the timetable for initiating complementary foods introduced by the Iranian Ministry of Health and Medical Education.

The two groups were matched for sex, weight and height of the infants. All mothers received mother and child health care on a regular basis, and instructions about the correct practice and techniques of breastfeeding. At the time of entrance to the study (when the infants were 4 months old) the instructions were repeated, and only the mothers whose breastfeeding techniques were correct entered the study. Mothers who wanted to begin complementary foods were instructed about appropriate kinds of food and when to give them, i.e. after breastfeeding.

\section{Data collection}

The infants' weight and height were measured at entry to the study at 4 months and at the end of age 5 and 6 months. Gestational age and birth weights were obtained from official birth certificates. Infant weight were measured to the nearest $10 \mathrm{~g}$ using Seca scales with a light cover at the end of 4, 5 and 6 months. Infant length was measured to the nearest $1 \mathrm{~mm}$ using a re-

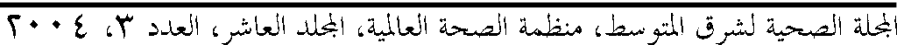


cumbent board. The reliability of the weighing scales was checked using a $1 \mathrm{~kg}$ standard mass on a daily basis.

Mothers were asked to bring their infants to the health centres for vaccination at age 4.5 months, and at this visit we confirmed their infant feeding practices.

All mothers were instructed to bring their infant to the health centre if he/she had any symptoms such as fever, cough or diarrhoea. Infants who were ill or who did not have normal weight gain were referred to the physician at the health care centres. The physicians recorded their diagnoses and referred the infants and/or prescribed drugs as necessary. For infants without normal weight gain, health education was given and mothers were advised to continue the selected method of feeding. To obtain more complete morbidity data, mothers were also asked about any illnesses that were not presented to the health centre.

\section{Data analysis}

Mean, standard deviation, and 95\% confidence intervals (CI) were calculated for all length and weight measures. Comparison of growth between the 2 groups were made using the Student $t$-test, and a chisquared test was used to compare the rate of morbidity in the two groups. Relative risk (RR) of illness was calculated.

\section{Results}

As shown in Table 1, the exclusively breastfed infants and those who received complementary foods were similar in terms of sex, weight and height at entry to the study (end of age 4 months), and maternal age and education. Although significantly more mothers who breastfed had attended antenatal care, both groups had received regular care at the health centres for 4 months before the study started.
During the study, 2 infants in the exclusively breastfed group and 5 in the complementary food-fed group were excluded for not complying with the selected method of feeding.

The comparison of growth measures of exclusively breastfed and complementary food-fed infants showed no difference in infants' weight at age 5 months $(7257 \pm$ $688 \mathrm{~g}$ versus $7262 \pm 765 \mathrm{~g}, P=0.96)$ or 6 months $(7719 \pm 763 \mathrm{~g}$ versus $7762 \pm 843$ $\mathrm{g}, P=0.95$ ) (Table 2). There were also no significant differences in length after age 5 months $(64.8 \pm 3.0 \mathrm{~cm}$ versus $64.9 \pm 2.9$ $\mathrm{cm}, P=0.8)$ or 6 months $(66.5 \pm 3.0 \mathrm{~cm}$ versus $66.6 \pm 3.1 \mathrm{~cm}, P=0.86)$.

There were no significant differences in weight gain $(922 \pm 500 \mathrm{~g}$ versus $1015 \pm$ $419 \mathrm{~g}, P=0.86)$ and length gain $(3.6 \pm 1.3$ $\mathrm{cm}$ versus $3.5 \pm 1.1 \mathrm{~cm}, P=0.7$ ) from 4 to 6 months between exclusively breastfed and complementary food-fed infants (Table 2).

Mean daily weight gain of exclusively breastfed infants was $16.7 \mathrm{~g}$ per day at 5 months and $15.4 \mathrm{~g}$ per day at 6 months of age versus $18.4 \mathrm{~g}$ per day and $15.5 \mathrm{~g}$ per day respectively in complementary foodfed infants.

Diarrhoeal diseases occurred in $11 \%$ of exclusively breastfed infants versus $27 \%$ of complementary food-fed infants $(P=$ $0.004 ; \mathrm{RR}=2.45 ; 95 \% \mathrm{CI}=1.20-4.67)$ and respiratory infections in $23 \%$ of exclusively breastfed infants versus $35 \%$ of complementary food-fed infants $(P=0.06$; $\mathrm{RR}=1.52 ; 95 \% \mathrm{CI}=0.97-2.37)$ in the $2-$ month study period.

\section{Discussion}

These results indicate that introducing complementary foods to breastfed infants does not significantly increase the rate of growth between ages 4-6 months. Dewey

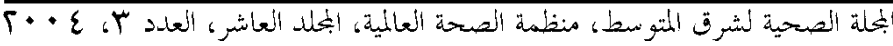




\begin{tabular}{|c|c|c|c|}
\hline Characteristic & $\begin{array}{c}\text { Exclusive } \\
\text { breastfeeding } \\
\quad(n=100)\end{array}$ & $\begin{array}{c}\text { Complementary } \\
\text { feeding } \\
(n=100)\end{array}$ & Significance \\
\hline Infant sex (\%) & & & $\chi^{2}=0.18 ; P=0.67$ \\
\hline Female & 49 & 45 & \\
\hline Male & 51 & 55 & \\
\hline Infant mean weight \pm SD $(g)$ & $6757 \pm 742$ & $6711 \pm 748$ & $t=0.54 ; P=0.59$ \\
\hline Infant mean length $\pm \mathrm{SD}(\mathrm{cm})$ & $62.9 \pm 29$ & $63.1 \pm 29$ & $t=0.46 ; P=0.63$ \\
\hline Maternal mean age \pm SD (years) & $24.3 \pm 4.7$ & $24 \pm 4.5$ & $t=0.49 ; P=0.65$ \\
\hline Maternal education level (\%) & & & $\chi^{2}=1.67 ; P=0.79$ \\
\hline Illiterate & 16 & 12 & \\
\hline Elementary school & 19 & 25 & \\
\hline Middle school & 36 & 35 & \\
\hline High school & 20 & 21 & \\
\hline Higher education & 9 & 7 & \\
\hline Mother had antenatal care $(\%)$ & & & $\chi^{2}=8.35 ; P=0.0035$ \\
\hline Yes & 73 & 52 & \\
\hline No & 27 & 48 & \\
\hline
\end{tabular}

Infants were aged 4 months at entry.

$\mathrm{n}=$ number of participants.

$\mathrm{SD}=$ standard deviation.

aMothers who received regular antenatal care at the health centres or those who made more than 6 antenatal visits at private clinics.

et al. showed no significant differences between the weight, length or head circumference of infants who were exclusively breastfed and infants who were breastfed but received twice daily complementary foods between 4 and 6 months of life [11]. Eregie and Abraham also showed no differences between the mean weights and rates of weight gain of exclusively or partially breastfed infants at each completed month for the first 6 months of life [5]. Simondon and Simondon reported no significant differences between the weight gain of infants who received complementary foods and those who predominantly received breast milk [6]. Our results are also similar to those of an interventional study from 4 to 6 months that showed neither weight gain nor length gain differed between two groups of infants who received exclusive breastfeeding or a $20 \%$ higher protein intake [7]. The results of the present study are also consistent with those from the DARLING [Davis Area Research on Lactation in Infant Nutrition and Growth] study that found that protein density of the infant diet was unrelated to growth throughout the first year of life [8]. Diaz et al. compared the monthly weight and length of fully breastfed infants with the WHO/National Center for Health Statistics data and showed that breastfeeding was adequate to support infant growth for the first 6 months of life [9]. 


\begin{tabular}{|c|c|c|c|}
\hline Variable & $\begin{array}{c}\text { Exclusive } \\
\text { breastfeeding } \\
\quad(n=98)\end{array}$ & $\begin{array}{c}\text { Complementary } \\
\text { feeding } \\
(n=95)\end{array}$ & Significance \\
\hline \multicolumn{4}{|l|}{ Mean weight \pm SD $(\mathrm{g})$} \\
\hline 5 months & $7257 \pm 686$ & $7262 \pm 765$ & $t=0.05 ; P=0.96$ \\
\hline 6 months & $7719 \pm 763$ & $7726 \pm 843$ & $t=0.06 ; P=0.95$ \\
\hline Increase 4-6 months & $922 \pm 500$ & $1015 \pm 419$ & $t=0.98 ; P=0.86$ \\
\hline \multicolumn{4}{|l|}{ Mean length \pm SD $(\mathrm{cm})$} \\
\hline 5 months & $64.8 \pm 30$ & $64.9 \pm 29$ & $t=0.15 ; P=0.8$ \\
\hline 6 months $(\mathrm{cm})$ & $66.5 \pm 3.0$ & $66.6 \pm 3.1$ & $t=0.17 ; P=0.86$ \\
\hline Increase 4-6 months & $3.6 \pm 1.3$ & $3.5 \pm 1.1$ & $t=0.59 ; P=0.5$ \\
\hline Diarrhoea (\%) & & & $\chi^{2}=8.3 ; P=0.004$ \\
\hline Yes & 11 & 27 & \\
\hline No & 89 & 73 & \\
\hline Respiratory infection (\%) & & & $\chi^{2}=3.44 ; P=0.06$ \\
\hline Yes & 23 & 35 & \\
\hline No & 77 & 65 & \\
\hline
\end{tabular}

$\mathrm{n}=$ number of participants.

$\mathrm{SD}=$ standard deviation.

In a study in Honduras, infants given solid foods consumed less breast milk after solid foods were introduced [13]. The displacement of breast milk occurs when solid foods are introduced, as the time spent breastfeeding declines and breast milk intake decreases $[9,11]$. Hop et al. showed that from 3 to 60 months of age exclusively breastfed infants gained more weight compared with partially breastfed and weaned infants [12].

In our study, the rates of both diarrhoea and respiratory infections were relatively high in both groups. However, the rate of diarrhoea between ages 4 and 6 months was significantly lower $(P=0.004)$ in exclusively breastfed infants than in complementary food-fed infants $(11 \%$ versus $27 \%$ ) and respiratory infections were also lower ( $23 \%$ versus $35 \%)$. The higher rate of diarrhoea in complementary food-fed infants may be because foods were not hygienically prepared. There is also evidence that intake of breast milk provides an effective defence against infections [14].

Although daily infant weight gains in both groups in this study (from $15.6 \mathrm{~g}$ to $18.7 \mathrm{~g}$ per day) were lower than that in the Honduras and DARLING studies [7,13], we conclude that exclusive breast feeding is not likely to limit growth between 4 and 6 months of age. Exclusive breastfeeding is superior at least until an infant is 6 months of age.

\section{Acknowledgements}

This study was supported by a grant from the Meshed University of Medical Sciences

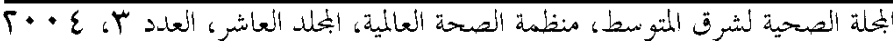


Vice Chancellor for Research Affairs. We appreciate the contribution of our colleague, Mrs M. Kordi, and also the contribution of Family Health Department of the
Province Health Centre. We thank health workers and colleagues who helped us in data collection and the mothers and children who participated in this study.

\section{References}

1. Healthy eating for healthy babies. In: Dudek SG, ed. Nutrition essentials for nursing practice, 4th ed. Philadelphia, Lippincott Williams and Wilkins, 2001: 280-320.

2. WHO/UNICEF. Innocenti declaration on the protection, promotion and support of breastfeeding, August 1990. Available at http://www.waba.org.br/inno.htm (accessed January 2004).

3. Waterlow JC, Thomson AM. Observations on the adequacy of breastfeeding. Lancet, 1979, 2:238-42.

4. Waterlow JC et al. Faltering in infant growth in less-developed countries. Lancet, 1980, 2:1176-8.

5. Eregie CO, Abraham R. Studies on exclusive breastfeeding: observations on the adequacy of breastmilk as sole nutrient for the first six months of life. International child health: a digest of current information, 1997, 8(4):49-54.

6. Simondon KB, Simondon F. Age at introduction of complementary food and physical growth from 2 to 9 months in rural Senegal. European journal of clinical nutrition, 1997, 51(10):703-7.

7. Dewey KG et al. Do exclusively breastfed infants require extra protein? Pediatric research, 1996, 39(2):303-7.

8. Heinig MJ et al. Energy and protein intakes of breast-fed and formula fed infants during the first year of life and their association with growth velocity: the DARLING [Davis Area Research on Lac- tation in Infant Nutrition and Growth] study. American journal of clinical nutrition, 1993, 58:152-61.

9. Diaz $\mathrm{S}$ et al. Breast-feeding duration and growth of fully breast-fed infants in a poor urban Chilean population. American journal of clinical nutrition, 1995 , 62:371-6.

10. Cohen $R$ et al. Determinants of growth from birth to 12 months among breastfed Honduran infants in relation to age of introduction of complementary foods. Pediatrics, 1995, 96:504-10.

11. Dewey KG et al. Age of introduction of complementary foods and growth of term, low-birth-weight, breast-fed infants: a randomized intervention study in Honduras. American journal of clinical nutrition, 1999, 69:679-86.

12. Hop LE et al. Premature complementary feeding is associated with poorer growth of Vietnamese children. Journal of nutrition, 2000, 130(11):2683-90.

13. Cohen RJ et al. Effects of age of introduction of complementary foods on infant breast milk intake, total energy intake and growth: a randomised intervention study in Honduras. Lancet, 1994, 344: 288-93.

14. Host resistance factors and immunologic significance of human milk. In: Lawrence RA, Lawrence RM, eds. Breastfeeding: a guide for the medical profession, 5th ed. St Louis, Mosby, 1999:217-332. 